\title{
Biopreservative Action of Bacteriocin from Pediococcus pentosaceus on the Microbial Load of Apple Juice
}

\author{
Riyanka Majumder, Ankita Aditya, Sreyosi Dey, Jannatul Firdous Siddique, Nivetha Anbalagan, \\ Subathra Devi, Mohanasrinivasan Vaithilingam*
}

School of Bio Sciences and Technology, Vellore Institute of Technology, Vellore, Tamil Nadu, INDIA.

\begin{abstract}
Aim: The aim of the study is to explore the bio preservative role of Pediococcus pentosaceus. Background: Bacteriocins are proteinaceous or peptidic in nature produced by lactic acid bacteria and generally recognized as safe (GRAS). It ranges from 2 to $200 \mathrm{kDa}$ in molecular weight. It inhibits the growth of similar or closely related bacterial strains. Materials and Methods: In this experiment, "Appam batter" has been taken as our sample, collected from Vellore city. The sample was fermented for seven and fourteen days simultaneously from which $1 \mathrm{~mL}$ of the samples were taken and inoculated in $100 \mathrm{~mL}$ of production media consist of $3 \%$ skim milk. The bacteria were allowed to grow for 24 hrs and serially diluted and spread plate was done on MRS agar plate. Seventeen bacterial strains were isolated. The preliminary assays were carried out to identify the bacteria as Lactobacillus species, such as Gram staining and catalase. All the strains were screened for bacteriocin by agar well diffusion assay. The strains which showed zone of inhibition was further subjected to antibacterial activity. Results: The isolated strains were found to show a clear zone of inhibition against Listeria monocytogenes MTCC 5260 used as the indicator strain. Further the isolated strains were tested for antimicrobial activity against certain food borne pathogens which includes Staphylococcus aureus MTCC 5257, Salmonella typhi MTCC2501, Escherichia coli MTCC 2089 and Pseudomonas aeruginosa MTCC 2242. The isolated strain VITABO1 showed a broad spectrum activity against all the pathogens with a highest zone of inhibition of $13 \mathrm{~mm}, 12800(\mathrm{AU} / \mathrm{mg})$ and thus subjected to 16srRNA molecular level analysis and found out to be Pediococcus pentosaceus $\mathrm{MH134499}$. The isolate upon characterization showed to be heat stable at $60^{\circ} \mathrm{C}$ and optimum $\mathrm{pH}$. On purification it has a specific activity of 325.20 (AU/ $\mathrm{mg}$ ) with a final yield of 3.12 . The molecular weight of the bacteriocin was found to be $17 \mathrm{kDa}$. Conclusion: The supernatant was mixed with apple juice and checked for its bio preservative effect. Decrease in colonies was found to be $26.82 \%$.
\end{abstract}

Key words: Appam batter, Lactic Acid Bacteria, Purification, Bacteriocin, Apple juice, Preservative.

\section{INTRODUCTION}

The bacteriocins are considered to be or peptidic or proteinaceous toxins. They are obtained by bacteria to inhibit the growth of bacterial strains that are similar or closely related. They have similarity to paramecium and yeast killing factors and are functionally, structurally and ecologically diversified. ${ }^{1}$ Lactic Acid Bacteria (LAB) of different strains are involved with systems related to food producing bacteriocins which exhibit bacteriocidal activity against closely related organisms ${ }^{2}$ bacteriocins that are isolated by using gram positive bacteria have broad inhibitory spectrum and might be used in various practical applications as anti microbial agents. ${ }^{3}$ This anti microbial property has extended the shelf life of many fermented food products. ${ }^{4}$ Most
Submission Date: 28-06-2020; Revision Date: 05-11-2020; Accepted Date: 08-02-2021

DOI: 10.5530/ijper.55.1s.56 Correspondence: Dr. Mohanasrinivasan $V$ School of Bio Sciences and Technology, Vellore Institute of Technology, Vellore-632014, Tamilnadu, INDIA.

Phone no: +91-9486802902 Email id: v.mohan@vit.ac.in

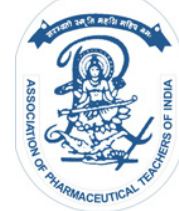

www.ijper.org 
bacteriocins are sensitive to certain proteolytic enzymes and are heat stable. LABs is playing a major role in production of aromatic compounds, food preservation and microbiological stability. ${ }^{5}$ They have also been widely used as starter culture where LABs produced bacteriocins. In recent years, $\mathrm{LAB}$ have grabbed the attention for their potential use as biopreservatives in food which has resulted in the reduction of the use of chemical preservatives. ${ }^{6}$ The preservation factors elaborated by LAB are known as "bacteriocins" and have been identified as "peptides". Raw food materials are generally preserved by lactic acid fermentation. ${ }^{7}$ Fermentive activities are also performed by LAB in food products which may inhibit the growth of pathogenic bacteria growing on them.

In the preservation and processing of food materials, technologies help to maintain the nutrition values and ensures food safety. Many chemicals are being used to preserve foods for long durations in order to inactivate the food borne pathogens. ${ }^{8}$

\section{MATERIALS AND METHODS}

Mann Ragosa sharpe agar (MRS), Skim mik, Nutrient broth were purchased from HiMedia. The indicator strain such as pathogen was procured from MTCC. All the reagents used were analytical grade.

\section{Isolation and Identification of Bacterial Strains}

The research was performed from July to October 2019 to isolate and identify the naturally producing Lactic acid Bacteria from fermented appam batter sample. Appam batter were aseptically collected using sterilized sample bottles from Vellore district, Tamil Nadu, India. The sample was kept for fermentation at $37^{\circ} \mathrm{C}$ for 7-14days. The appam batter mixture was mixed with skimmed milk (10:3) incorporated in MRS broth media (Hi-media, India) and incubated at $37^{\circ} \mathrm{C}$ for $48 \mathrm{hr}$. Samples were serially diluted from $10^{-1}$ to $10^{-8}$ in sterile normal saline. A volume of $0.1 \mathrm{ml}$ of proper dilutions was spread plated on De Man Rogosa Sharpe (MRS) agar plates and incubated for $48 \mathrm{hr}$ at $30^{\circ} \mathrm{C}$. 'Several streak were made to obtain pure isolate. Isolates with colony morphology similar to lactic acid bacteria were selected and sub cultured in MRS medium to obtain pure culture. Pure culture strains were numbered isolates from appam batter sample VITAB01 to VITAB13 and maintained at $-20^{\circ} \mathrm{C}$ in MRS broth with $20 \%$ glycerol and enriched in MRS broth by incubating at $37^{\circ} \mathrm{C}$ for $24 \mathrm{~h}$ for future study. These cultures were retrieved twice in MRS broth before the experiment.

\section{Screening for bacteriocin activity from lactic acid bacteria}

Isolated strains ware grown in MRS broth at $37^{\circ} \mathrm{C}$ for $48 \mathrm{hr}$. After incubation, centrifugation of the broth was performed at $10000 * \mathrm{~g}$ for $25 \mathrm{~min}$ at $4^{\circ} \mathrm{C}$. The pellet were discarded and the supernatant were collected. Thus the supernatant that was free of cells were used as crude bacteriocin and were carried out for further assays. Screening for bacteriocin producing bacteria was carried out using extracellular protein as cell free supernatant. LAB was prepared in MRS broth and incubated for $48 \mathrm{~h}$ at $37^{\circ} \mathrm{C}$. After incubation the isolates were centrifuged at $8,000 \mathrm{rpm}$ for $20 \mathrm{~min}$ at $4^{\circ} \mathrm{C}$. Bacteriocin production from the isolated strains against Listeria monocytogens as an indicator strain were carried out, by performing agar well diffusion assay (AWDA) under aerobic condition. Mueller Hinton Agar plates were swabbed with $100 \mu \mathrm{L}$ of indicator microorganism Listeria monocytogens. $5 \mathrm{~mm}$ deep wells were cut and $100 \mu \mathrm{L}$ of the cell free culture supernatant (crude bateriocin) of all the isolated strains were added into each well. Incubation of the plates were done for $3 \mathrm{hrs}$ at $4^{\circ} \mathrm{C}$ which was followed by incubation at room temperature for $24 \mathrm{hr}$. The zone of inhibition were measured in order to determine the zone of inhibition. ${ }^{10}$

\section{Determination of Antibacterial activity}

Staphylococcus aureus (5257), Salmonella typhi (2501), Escherichia coli (2089) and Pseudomonas fuoroscens (2173) Listeria monocytogenes (MTCC 5260) used in the experiement were purchased from the Micobial Type Culture Collection (MTCC), Pune. The assay was carried out similarly using AWDA as described above. ${ }^{11}$

\section{Biochemical characterization of the potent isolate}

A potent isolate VITAB1 isolated from the appam batter sample, showed the most intense antibacterial activity and was selected for further work. Pure culture of strain was tested for Indole test, Methyl red, Voges proskeur and citrate utilization test. Characteristics of the isolate were compared with data from Bergey's Manual of Determinative Bacteriology (Bergey et al. 1923). ${ }^{12}$

\section{Molecular characterization}

The strain was further identified by $16 \mathrm{~S}$ rRNA gene sequencing for species level identification. The nucleic acids of the isolate were extracted using a DNA purification kit (Amnion Biosciences Pvt Ltd, India), according to the manufacturer's instructions. Two primers namely Forward (5'AGAGTT'TGATCCTGGCTCAG3') and Reverse 
(5'AAGGAGGTGATCCAGCCGCA3') were used for the DNA amplification isolated from VITAB1 isolate for 16S rRNA sequencing. The obtained sequences were subjected to BLAST in the NCBI database. Phylogenetic tree was constructed in MEGA 4.0.2 using neighbor-joining (NJ) method. ${ }^{13}$

\section{Characterization}

Heat stability and effect of $\mathrm{pH}$

Various temperature like $37^{\circ} \mathrm{C}, 60^{\circ} \mathrm{C}, 100^{\circ} \mathrm{C}$ and $120^{\circ} \mathrm{C}$ were applied to the sample for $15 \mathrm{~min}$. The samples were cooled down and were checked for its activity on by using agar well diffusion assay. Partially purified bacteria of about $5 \mathrm{ml}$ were collected in several test tubes. The $\mathrm{pH}$ values were adjusted of $\mathrm{pH}$ was done at 2, 4, 7, 9 and 12. The MRS broth was prepared and adjusted to $\mathrm{pH} 2$ to 4 using Acetic acid buffer followed by 7 using Sodium phosphate buffer and $\mathrm{pH} 9$ to 12 was maintained with Glycine buffer. Also, the sentence was reframed in the revised manuscript. It was kept at room temperature for $2 \mathrm{hr}$ and checked for it activity on well diffusion agar. ${ }^{14}$

\section{Effect of enzyme on bacteriocin activity (proteolytic assay)}

Partially purified protein sample of $1 \mathrm{~mL}$ was collected in a test tube and mixed with proteinase $\mathrm{K}(1 \mathrm{mg} / \mathrm{ml})$ and kept at $4^{\circ} \mathrm{C}$ for overnight. Further the untreated and treated samples were boiled for $2 \mathrm{~min}$ at $100^{\circ} \mathrm{C}$, in order to inactivate the enzyme. Agar well diffusion assay were performed to check the activity. ${ }^{15}$

\section{Purification of bacteriocin}

The $300 \mathrm{ml}$ culture of Pediococcus pentosaceus was incubated for $48 \mathrm{hr}$ at $30^{\circ} \mathrm{C}$. the purification technique has been carried out with modification of the process as described by Nieto Lozano JC et al. ${ }^{16}$

The sample was subjected to $80 \%$ ammonium sulfate precipitation. The precipitate obtained was further dissolved in sodium acetate buffer $1 \mathrm{mM}(\mathrm{pH} \mathrm{5)}$. The sample was centrifuged $\left(4^{\circ} \mathrm{C}, 4000 \mathrm{rpm}, 30 \mathrm{~min}\right)$ using ultrafiltration membrane (Amicon Ultra-15, Millipore, India) with a $10 \mathrm{kDa}$ molecular cutoff. The permeate and retentate were both collected and and the active fraction was subjected to gel filtration chromatography using self-packed Sephadex G-50 column (1.5 in diameter, $15 \mathrm{~cm}$ gel bed height, $1 \mathrm{~mL}$ sample volume) equilibrated with sterile column buffer, $1 \mathrm{mM}$ Sodium acetate buffer $(\mathrm{pH} 5)$. All the twenty five filtrate fractions obtained were pulled off and in each step of the purification, the protein concentration and activity using Lowry's method and AWDA were checked consequetively. The molecular weight was determined using 12\% tricine SDS-PAGE and compared with standard protein marker $(4.6-42 \mathrm{kDa})$ bought from Genei.

\section{Application}

\section{Efficacy of bacteriocin as biopreservative}

Apple juice was refrigerated after adding $5 \%$ bacteriocin to it. ${ }^{17}$ Serial dilution from $10^{1}-10^{6}$ was performed. The plates were incubated at $37^{\circ} \mathrm{C}$ for $24 \mathrm{hr}$. The number of colony was calculated and compared with the control (without bacteriocin) the juice were further kept for a week and every day the microbial load was checked. ${ }^{18}$

\section{RESULTS AND DISCUSSION}

\section{Isolation and identification of bacterial strains}

Based on the colony morphology 13 different strains were isolated from appam batter samples. All 13 bacterial strains were characterized to be lactic acid bacteria based on the Grams and Catalase reaction. Out of 13 strains 3 are shown to be gram positive cocci and 10 were shown to be gram positive bacilli. All the isolates were shown to be negative for catalase reaction. From the results it was evident that bacilli were high in number compared to cocci. All the strain were subjected to antimicrobial activity against different food borne pathogens purchased from MTCC. The strain that produced bacteriocin was isolated from the source of appam batter and the selected strain Lactobacillus VITAB01 was identified as on its physiological and biochemical characteristic. The isolate was gram positive, rod shaped, oxidase positive and catalase negative displaying smooth round colonies on the MRS agar media.The morphological characterization of the isolates are shown in Table 1.

\section{Screening for bacteriocin activity from lactic acid bacteria}

The isolates VITAB01 VITAB02, VITAB03 and VITAB04 showed to produce bacteriocin with a clear zone of inhibition against the indicator organism.

\section{Determination of Antibacterial activity}

Among 13 isolates which were obtained from appam batter sample, one potent isolate VITAB01 were very effective against all 5 pathogens with high zone of inhibition. Among the rest VITAB02, VITAB03 and VITAB04 were resistant to E. coli and Pseudomonas fluoroscens. Other isolates from VITAB05 to VITAB13 were completely resistant to all pathogens. Isolates VITAB01 were considered for further studies such as biochemical, molecular and application. The bacteriocin 
isolated from the selected strains was treated against 4 different types of major food borne gram positive and gram-negative pathogens for antibacterial activity. The isolated bacteriocin showed inhibitory activity against Staphylococcus aureus MTCC 5257, Salmonella typhi MTCC2501, Escherichia coli MTCC 2089 and Pseudomonas fluoroscens MTCC 2173.

Among all the strain VITAB01 showed strong zone of inbition of $13 \mathrm{~mm}$ as shown (Table 2).

\section{Biochemical characterization of potent isolate VITAB01}

The isolate VITAB01 showed Methyl red positive, Indole, voges prauskauer and citrate utilization test negative (Table 3).

\section{Molecular characterization}

$16 \mathrm{~S}$ rRNA was amplified using universal primers(forward and reverse). The amplified 16s rRNA was identified as

\begin{tabular}{|c|c|c|c|}
\hline \multicolumn{4}{|c|}{ Morphology } \\
\hline \multicolumn{4}{|c|}{$\begin{array}{c}\text { Table 1: The Gram's Reaction, Catalase test and } \\
\text { morphology of the } 13 \text { isolates were shown in the } \\
\text { table. }\end{array}$} \\
\hline Isolate No. & $\begin{array}{l}\text { Gram's } \\
\text { Reaction }\end{array}$ & $\begin{array}{c}\text { Catalase } \\
\text { Test }\end{array}$ & Shape \\
\hline VITAB01 & $\begin{array}{l}\text { Gram } \\
\text { Positive }\end{array}$ & Negative & $\begin{array}{c}\text { Cocci in chains and } \\
\text { tetrads }\end{array}$ \\
\hline VITAB02 & $\begin{array}{l}\text { Gram } \\
\text { Positive }\end{array}$ & Negative & Cocci in tetrads \\
\hline VITAB03 & $\begin{array}{c}\text { Gram } \\
\text { Positive }\end{array}$ & Negative & Bacilli in long rods \\
\hline VITAB04 & $\begin{array}{l}\text { Gram } \\
\text { Positive }\end{array}$ & Negative & Bacilli in long rods \\
\hline VITAB05 & $\begin{array}{l}\text { Gram } \\
\text { Positive }\end{array}$ & Negative & Bacilli in chains \\
\hline VITAB06 & $\begin{array}{l}\text { Gram } \\
\text { Positive }\end{array}$ & Negative & Bacilli in chains \\
\hline VITAB07 & $\begin{array}{l}\text { Gram } \\
\text { Positive }\end{array}$ & Negative & Cocci in chains \\
\hline VITAB08 & $\begin{array}{l}\text { Gram } \\
\text { Positive }\end{array}$ & Negative & Bacilli in long rods \\
\hline VITAB09 & $\begin{array}{l}\text { Gram } \\
\text { Positive }\end{array}$ & Negative & $\begin{array}{l}\text { Bacilli in short rods } \\
\text { arranged singly }\end{array}$ \\
\hline VITAB10 & $\begin{array}{l}\text { Gram } \\
\text { Positive }\end{array}$ & Negative & Bacilli in long rods \\
\hline VITAB11 & $\begin{array}{l}\text { Gram } \\
\text { Positive }\end{array}$ & Negative & Bacilli in long rods \\
\hline VITAB12 & $\begin{array}{l}\text { Gram } \\
\text { Positive }\end{array}$ & Negative & Bacilli in long rods \\
\hline VITAB13 & $\begin{array}{l}\text { Gram } \\
\text { Positive }\end{array}$ & Negative & Bacilli in chains \\
\hline
\end{tabular}

Pediococcus pentosaceus (NCBI accession no. MH134499) as Figure 1.

\section{Characterization}

\section{Heat stability and effect of pH}

At different temperatures (37, 60, 100 and 121C), the protein activity was checked. The inhibition zones were observed at 37 and $60^{\circ} \mathrm{C}$. The maximum inhibitory zone was measured at $\mathrm{pH} 6$ as shown in Figure 2. Result obtained by Saad MA et al. ${ }^{19}$ showed the activity was stable even after heated for $30 \mathrm{~min}$ at $100^{\circ} \mathrm{C}$, which showed a better performance than this study.

\section{Effect of enzyme on bacteriocin activity (proteolytic assay)}

No zone of inhibition was found when the protein of interest was treated with proteinase $\mathrm{K}$ as shown in Figure 3. So it can be concluded that the partially purified protein sample got degraded and confirmed to be proteinaceous in nature. Similar result by Saad MA et al. ${ }^{19}$ on the activity of Lactobacillus Acidophilus bacteriocin supported the present study.

\section{Purification of Bacteriocin}

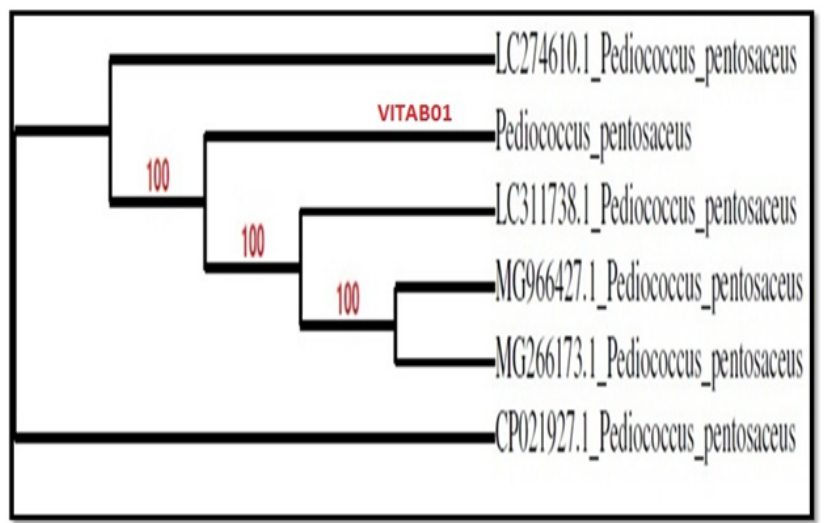

Figure 1: The phylogenetic position of the Pediococcus pentosaceus strain among neighbouring species.
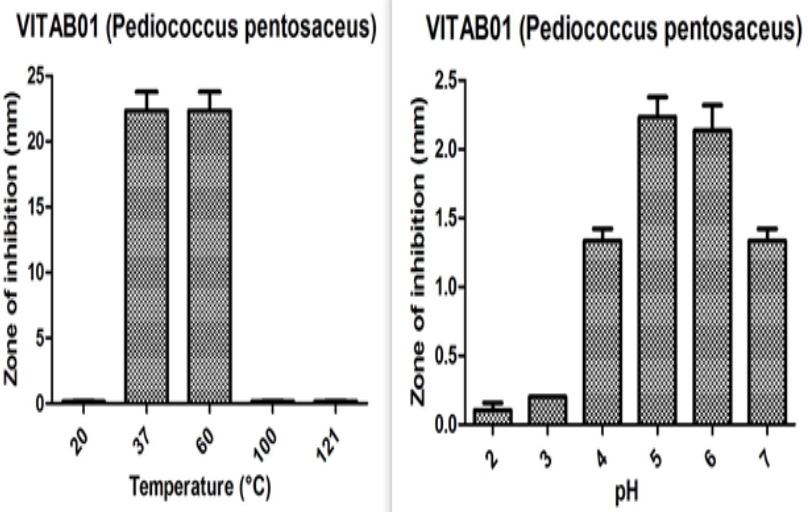

Figure 2: (a) Heat stability (b)Effect of pH on bacteriocin. 
The cell free supernatant protein concentration was $100 \mathrm{mg}$ with specific activity of 128 (AU/mg). The purification data as obtained showed, the protein of interest got precipitated at $80 \%$ ammonium sulfate saturation. The total protein concentration of the precipitate was found to be $40 \mathrm{mg}$, with 160.00 as the specific activity. The precipitate of $19.20 \mathrm{mg}$ on being subjected to ultrafiltration, was found in the retentate of the $10 \mathrm{kDa}$ ultrafiltration membrane with specific activity of $166.66(\mathrm{AU} / \mathrm{mg})$. In the gel filtration chromatography, the protein was loaded and all the fractions were pulled off and checked at $220 / 280 \mathrm{~nm}$ using UV Visible spectrophotometer. The protein concentration of the active fraction was found to be $1.23 \mathrm{mg}$, with $325.20(\mathrm{AU} / \mathrm{mg})$ specific activity, 2.54 purification fold and a final yield of 3.12 as shown in Table 4. The molecular weight of the purified was determined using $12 \%$ Tricine SDS-PAGE and observed to be $17 \mathrm{kDa}$ as shown in Figure 4. Similarly, Marianne et al. ${ }^{20}$ reported the specific activity of pediocin was found to be $300 \mathrm{AU} / \mathrm{mg}$ using the new procedure for purification. There are reports which showed very less yield of $0.98 \%$ for Enterocin LR $/ 6 .{ }^{21}$ Our results shows better specific activity when compared with the report

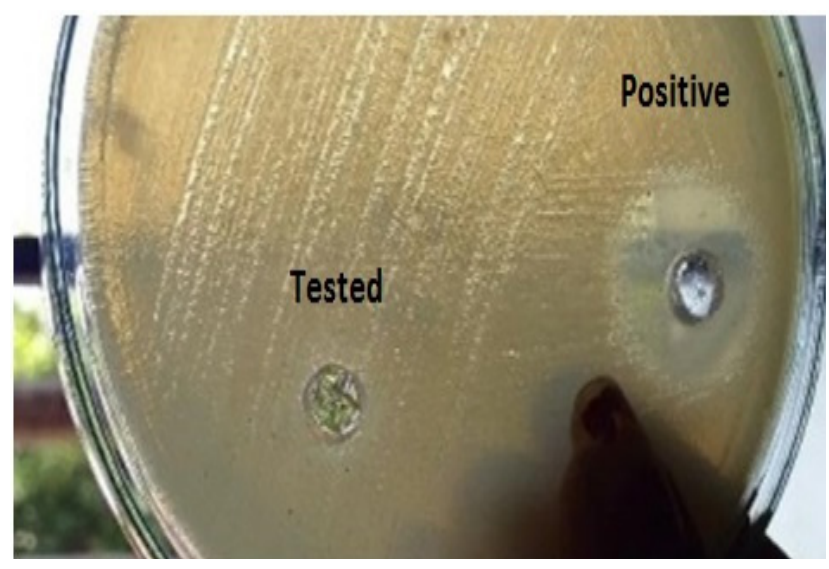

Figure 3: Effect of enzyme on the bacteriocin. The positive control without the enzyme showed a clear zone, with Proteinase $\mathrm{K}$ treatment, no zone of inhibition was obtained.

\begin{tabular}{|c|c|c|c|c|}
\hline \multicolumn{4}{|l|}{ Antibacterial activity } \\
\hline \multicolumn{3}{|c|}{ Table 2: The table shows the antibacterial activity of the four major potent lactic acid isolates. } \\
\hline Isolates & E.coli & Pseudomonas fluoroscens & Salmonella typhi & Staphylococcus aureus \\
\hline VITAB01 & ++ & + & ++ & + \\
\hline VITAB02 & ++ & + & - & - \\
\hline VITAB03 & ++ & + & - & - \\
\hline VITAB04 & ++ & ++ & - & - \\
\hline
\end{tabular}

\# Plus(+) indicates zone of inhibition. $(+)<1 \mathrm{~cm},(++)>1 \mathrm{~cm},(+++)>1.5 \mathrm{~cm}$

\section{Biochemical characterization}

\section{Table 3: The table shows the biochemical characteristic of the potent isolate.}

\begin{tabular}{|c|c|c|c|c|}
\hline Isolate & Indole & Methyl red & Voges proskeur & Citrate utilization \\
\hline VITAB01 & $(-) v e$ & $(+) v e$ & $(-) v e$ & $(-) v e$ \\
\hline
\end{tabular}

\begin{tabular}{|c|c|c|c|c|c|c|}
\hline \multicolumn{7}{|c|}{ Purification table } \\
\hline \multicolumn{2}{|c|}{ Table 4: The purification table shows the increase in specific activity with each purification step. } \\
\hline Purification fraction & $\begin{array}{c}\text { Total Volume } \\
\text { (ml) }\end{array}$ & $\begin{array}{c}\text { Total } \\
\text { bacteriocin } \\
\text { activity (AU/ } \\
\mathbf{m L}\end{array}$ & $\begin{array}{c}\text { Total Protein } \\
\text { (mg) }\end{array}$ & $\begin{array}{c}\text { Specific } \\
\text { activity (AU/ } \\
\text { mg) }\end{array}$ & Fold Purification & Yield (\%) \\
\hline Cell free supernatant (CFS) & 300 & 12800 & 100.00 & 128.00 & 1 & 1.25 \\
\hline $\begin{array}{c}\text { Ammonium sulphate } \\
\text { precipitation (80\%) }\end{array}$ & 150 & 6400 & 40.00 & 160.00 & 50 \\
\hline $\begin{array}{c}\text { Ultra-filtration (10kDa) } \\
\text { Gel filtration } \\
\text { chromatography }\end{array}$ & 10 & 3200 & 19.20 & 166.66 & 1.30 & 25 \\
\hline
\end{tabular}



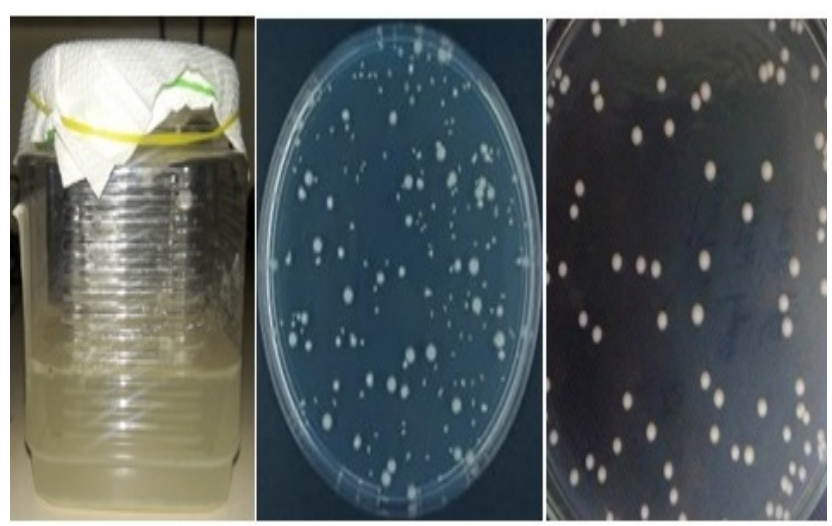

Figure 5: (a) The apple juice (b)Colonies before and (c) after the application of bacteriocin like substance.

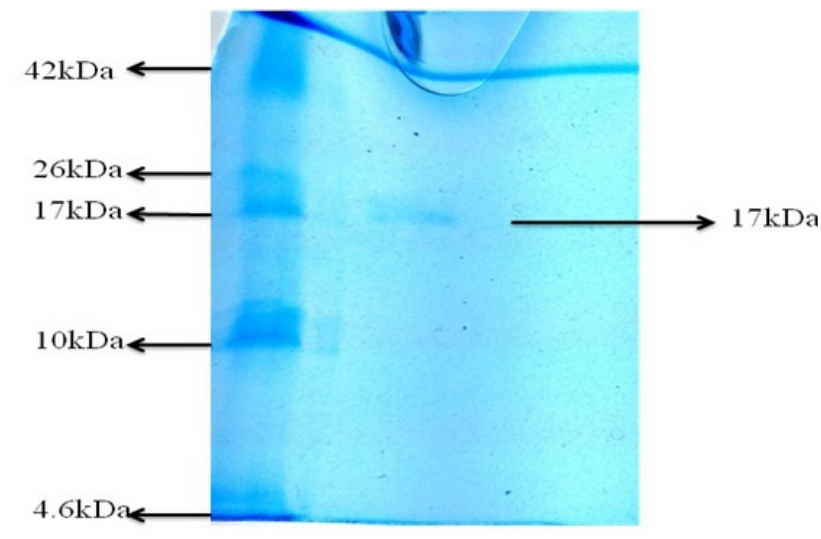

Figure 4: The $12 \%$ Tricine SDS-PAGE showed a single band at $17 \mathrm{kDa}$ with comparion to the protein marker (4.6- $42 \mathrm{kDa})$.

of Tichaczek et al. ${ }^{22}$ for bacteriocin purified by the earlier standard procedure shows a specific activity of about 45 $\mathrm{AU} / \mathrm{mg}$ for $400 \mathrm{ml}$.

\section{Application}

\section{Efficacy of bacteriocin as biopreservative}

A hand on preservative assay was done to check the activity of the partially purified protein sample on apple juice. The result showed that there was a drastical decrease in the microbial count on action with the protein sample ashown in Figure 5.

Number of colonies observed on $10^{-6}$ dilution of apple juice $=82$

$\mathrm{CFU} / \mathrm{mL}=$ (No. of colonies $*$ dilution factor) $/$ volume of culture

$$
\begin{aligned}
& =\left(82 * 10^{-6}\right) / 0.1 \\
& =8.2 * 10^{-4} \mathrm{Cfu}
\end{aligned}
$$

On action of bacteriocin the colony count reduced to 60.

Cfu per $\mathrm{mL}=($ no. of colonies $*$ dilution factor $) /$ volume of culture

$$
=\left(62 * 10^{-6}\right) / 0.1
$$

$$
=62 * 10^{-4} \mathrm{Cfu}
$$

Percentage decrease in colonies $=100-[(60 / 82) * 100]$

$$
=26.82 \%
$$

Our result suggested that bacteriocin producing Pediococcus pentosaceus naturally occurs and survives in appam batter.

In the present study used phenotypic characteristics for grouping the isolates and employed 16s rRNA sequence analysis to identify the representative isolate. The representative isolate has high similarity with the reference strain Pediococcus pentosaceus. The antibacterial activity exhibited by Pediococcus pentosaceus was proteinaceous in nature and stable at $60^{\circ} \mathrm{C}$ and in $\mathrm{pH}$ 6. Thus the study performed revealed that the protein from Pediococcus pentosaceus VITAB01 isolated from appam batter contains a wide range of inhibitory activity against pathogens like Staphylococcus aureus MTCC 5257, Salmonella typhi MTCC 2501, Escherichia coli MTCC 2089 and Pseudomonas fluoroscens MTCC 2173. It also showed a considerable decrease in microbial count when applied to apple juice. Similar study has also carried out by Mohammad Shaokat Ali et al..$^{23}$ which support this study. In their case the microbial count was reported to reduce drastically on incorporation of $5 \%$ bacteriocin, but in this study it has been clearly stated the reduction found to be $26.82 \%$.

For biopreservative effect of refrigerated food product for the longevity the organism producing bacteriocin Pediococcus pentosaceus will probably be useful in food products as it showed to maintain the microbial load as low as the $24^{\text {th }} \mathrm{hr}$ till $4^{\text {th }}$ after incorporation. Hence this property will be useful to extend the shelf life of the refrigerated food material approximately for 3-4 days as can be concluded.

\section{CONCLUSION}

The present study revealed the bacteriocin from Pediococcus pentosaceus isolated from natural lactic acid fermentation of appam batter posess a wide variety of inhibitory activity against Staphylococcus aureus MTCC 5257, Salmonella typhi MTCC 2501, Escherichia coli MTCC 2089 and Pseudomonas fuoroscens MTCC 2173. Since lactic acid fermentation is employed mostly for the development of flavor and taste of fermented products, the production of bacteriocin in such products assumes more significance as biopreservative.

\section{ACKNOWLEDGEMENT}

We are thankful to seed money of Vellore Institute of Technology and the management for providing the necessary fund and support. 


\section{CONFLICT OF INTEREST}

The authors declare no conflict of interest.

\section{ABBREVIATIONS}

LGRAS: Generally Recognized As Safe; MTCC: Microbial Type Culture Collection; LAB: Lactic Acid Bacteria; MRS: De Mann Rogosa and Sharpe; AWDA: Agar Well Diffusion Assay; BLAST: Basic Local Alignment Search Tool; NCBI: National Centre for Biotechnology Information; MEGA: Molecular Evolutionary Genetics Analysis; SDS-PAGE: Sodium Dodecyl Sulfate-Polyacrylamide Gel Electrophoresis; CFU: Cell-Free Unit.

\section{REFERENCES}

1. Bali V, Panesar PS, Bera MB. Isolation, screening and evaluation of antimicrobial activity of potential bacteriocin producing lactic acid bacteria isolate. Microbiol J. 2011;1(3):113-9.

2. Cassia RN, Adriano B. Production of bacteriocin-like substances by lactic acid bacteria isolated from regional ovine cheese. Braz J Microbiol. 2010;41(4):1009-18

3. Torodov SD, Dicks LMT. Bacteriocin production by Lactobacillus pentosus ST7 12BZ isolated from boza. Bra J Microbiol. 2007;38(1):166-72.

4. Sarika AR, Lipton AP, Aishwarya MS. Bacteriocin Production by a new isolate of Lactobacillus rhamnosus GPI under different culture conditions. Adv J Food Sci Technol. 2010;2(5):291-7.

5. Ravi V, Prabhu M, Subramanyam D. Isolation of bacteriocin producing bacteria from mango pulp and its antimicrobial activity. J Microbiol Biotech Res. 2011;1(2):54-63.

6. Karthikeyan V, Santhosh SW. Study of Bacteriocin as a Food Preservative and the L. acidophilus strain as probiotic. Pak J Nutr. 2009;8(4):335-40.

7. Mechal A, Kirane D. Antimicrobial activity of autochthonous lactic aicd bacteria isolated from Algerian traditional fermented milk "Raib". Afr J Biotechnol. 2008;7(16):2908-14

8. Nongpanga K, Aporn W, Duangtip M, Sukon T. Screeing and identification of Lactic acid bacteria producing antimicrobial compounds from pigs Gastrointestinal tracts. KMITL Sci Tech J. 2008;8(1):8-17.

9. Atta $\mathrm{Hm}$, Refaat BM, El-Waseif AA. Application of biotechnology for production, purification and characterization of peptide antibiotics produced by probiotic Lactobacills planatarum, NRRL B-227. Global J Biotech and Biochem. 2009;4(2):115-25.
10. Fossi B, Goghomu S, Tongwa M, Ndjouenkeu R, Cho-Ngwa F. Screening for bacteriocins producing probiotic bacteria from fermented sap of palm trees (Elaeis guineesis and Raffia sudanica): Production and partial characterization of bacteriocins. Journal of Applied Biotechnology and Bioengineering. 2017;2:17

11. Ren D, Zhu J, Gong S, Liu H, Yu H. Antimicrobial characteristics of lactic acid bacteria isolated from homemade fermented foods. Bio Med Research International. 2018.

12. MacFaddin JF. Biochemical tests for Identification of $3^{\text {rd }}$ Medical Bacteria. Philadelphia: Lippincott Williams and Wilkins. 2000;(3):363-7.

13. Suganthi V, Mohanasrinivasn V. Molecular Characterization of Potential Bacteriocin Producing Lactic Acid Bacteria and its Efficacy Against Food Borne Pathogens. Journal of Pure and Applied Microbiology. 2014;8(4):1-10.

14. Rajaram G, Manivasagam P, Thilagavathi B, Saravanakumar A. Purification and Characterization of a Bacteriocin produced by Lactobacillus lactis isolated from Marine Environment. Adv J Food Sci Technol. 2010;2(2):138-44.

15. Santini C, Baffoni L, Gaggia F, Granata M, Gasbarri R, DiGioia D, et al. Characterization of probiotic strains: An application as feed additives in poultry against Campylobacter jejuni. International Journal of Food Microbiology. 2010;141:S98-108.

16. Lozano JC, Meyer JN, Sletten K, Peláz C, Nes IF. Purification and amino acid sequence of a bacteriocin produced by Pediococcus acidilactici. Microbiology. 1992;138(9):1985-90.

17. Todorov SD, Mollendorff JWV, Moelich E, Muller N, Witthuhn RC, Dicks LM. Evaluation of potential probiotic properties of Enterococcus mundtii, its survival in Boza and in situ bacteriocin production. Food Technology and Biotechnology. 2009;47(2):178-91.

18. Yasmin A, Ashraf M, Arshad M, Muhammad G, Zahid M, Mustafa B. Determination of biopreservative effects of bacteriocins isolated from lactic acid producing bacteria against food spoiling fungi. International Journal of Current Microbiology and Applied Sciences. 2015;4:88-96.

19. Saad MA, Abdelsamei HM, Ibrahim E, Abdou AM, EISohaimy SA. Effect of $\mathrm{pH}$, heat treatments and proteinase $\mathrm{K}$ enzyme on the activity of Lactobacillus acidophilus bacteriocin. Benha Veterinary Medical Journal. 2015;28(1):210-5.

20. Marianne U, Havard HH, Ilia B, Nissen J, Gunnar F. Rapid Two-Step Procedure for Large-Scale Purification of Pediocin-Like Bacteriocins and Other Cationic Antimicrobial Peptides from Complex Culture Medium. Applied and Environmental Microbiology. 2002;68(2):952-6.

21. Hu CB, Malaphan W, Zendo T, Nakayama J, Sonomoto K. Enterocin X, a Novel Two-Peptide Bacteriocin from Enterococcus faecium KU-B5, Has an Antibacterial Spectrum Entirely Different from those of its Component Peptides. Appl Environ Microbiol. 2010;76(13):4542-5.

22. Tichaczek PS, Nissen-Meyer J, Nes IF, Vogel RF, Hammes WP. Characterization of the bacteriocinscurvacin a from Lactobacillus curvatus LTH1174 and sakacin P from L.sake LTH 673. Systematic and Applied Microbiology. 1992;15(3):460-8.

23. Mohammad SA, Ayesha B, MdForhad U, Shamima A. Biopreservative effect of bacteriocin in fruit juice preservation. Asian Australas J Biosci Biotechnol. 2016;1(3):435-40. 


\section{SUMMARY}

Lactic acid bacteria are considered to be a distinguished bacterial group because of their ability to produce lactic acid, natural antimicrobial peptide i.e., bacteriocins. Bacteriocins are antimicrobial peptides synthesized ribosomally which can be used as bio-preservative reducing the risk of chemical preservatives and also replacing the thermal treatments. The main aim of the study is to produce bacteriocin from Pediococcus pentosaceus isolated from appam batter to assess the bio-preservative aspect of apple juice.

- Among different isolates, one promising isolate VITAB01 Pediococcus pentosaceus was found positive for bacteriocin screening on Agar Well Diffusion Assay for foodborne pathogens such as E.coli, Pseudomonas aeruginosa, Salmonella typhi, and Staphylococcus aureus.

- The potent strain VITABO1 was further subjected to biochemical characterization and found to be Pedioccoccus by comparing with Bergey's manual and further identified as Pediocccoccus pentosaceus in 16S rRNA sequencing.

- Preliminary characterization confirms the zone of inhibition on heat stability at a maximum temperature of $37^{\circ} \mathrm{C}$ and $60^{\circ} \mathrm{C}$. The effect of bacteriocin is stable at $\mathrm{pH} 5$ and 6.

- Bacteriocin purified by using $80 \%$ ammonium sulfate precipitation method followed by $10 \mathrm{kDa}$ ultrafiltration membrane and fractionated in gel filtration chromatography (Sephadex G-50 column).

- The molecular weight was determined via a $10 \%$ SDS PAGE and found to be of $17 \mathrm{kDa}$ with a yield of $3.12 \%$ and increased with $325.20(\mathrm{AU} / \mathrm{mg})$ in a specific activity.

- Purified bacteriocin analysed for efficacy on bio preservative on the microbial load apple juice. In this case, the microbial count was reported to reduce drastically on the incorporation of $5 \%$ bacteriocin, but in this study, it has been clearly stated the reduction found to be $26.82 \%$.

- Hence this property will be useful to extend the shelf life of the refrigerated food material approximately for 3-4 days.

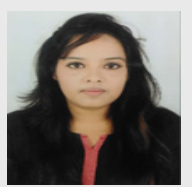

\section{About Authors}

Riyanka Majumder: Completed Masters in Biotechnology in 2019 from VIT, Vellore. Worked at Eurofins Advinus as a research intern and currently working as an Associate Research Scientist in DMPK department at Eurofins Advinus. Also pursuing MBA in marketing management from IMT, Ghaziabad.

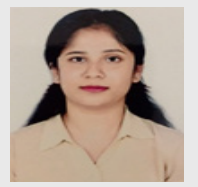

Ankita Aditya: Completed Masters in Biotechnology in 2019 from VIT, Vellore. Worked at Eurofins Advinus as a research intern and currently working as an Associate Research Scientist In DMPK department at Eurofins Advinus.

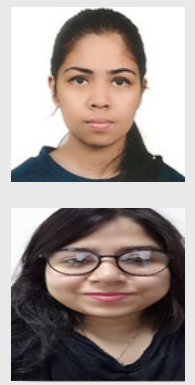

Sreyosi Dey: Completed Masters in Applied Microbiology in 2019 from VIT, Vellore. Also completed PGDM in Digital Marketing. Currently working as a marketing freelancer.

Jannatul Firdous Siddqiue: Pursuing Ph.D. (full-time- Scholar) in Industrial Microbiology at VIT, Vellore. Research interest is to work with protein and peptide based studies. Current focus is on the role of peptides from Lactic Acid Bacteria (LAB) as an anti-cancerous agent.

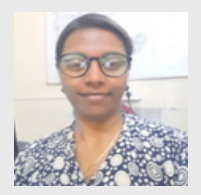

Nivetha A: Senior Research Fellow (SRF) - ICMR: She is pursuing a full-time Ph.D. in Industrial Microbiology at VIT, Vellore. Research focus is on the the production of beta-galactosidase for lactose free product development.

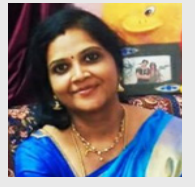

Dr. C. Subathra Devi is currently an Associate Professor at Vellore Institute of Technology, Vellore, Tamil Nadu, India. Her main research focus is on actinobacteria. Her lab is currently working on clot buster enzymes, actinokinases, nattokinase and recombinant streptokinase. Dr. Subathra"s lab focuses on a diverse array of actinobacteria related to anti-cancer, anti-bacterial and other bioactive metabolites. From her research lab two marine actinobacterial strains were deposited in National collection of industrial microorganisms (NCIM). She has published over 130 research papers, 3 books and 5 book chapters in the past 10 years in the field of microbial biotechnology. 
Dr. Mohanasrinivasan is a Microbiologist working as an Associate Professor at Vellore Institute of Technology, Vellore ,Tamil Nadu, India. He has vast experience in teaching and research for about 15 years. He has published 107 papers in reputed journals and filed two research patents. Currently his research is focused on industrial enzymes and proteins to combat myocardial infarction and bacterial proteins for biopreservation with the application of nanobiotechnology.

\section{PICTORIAL ABSTRACT}

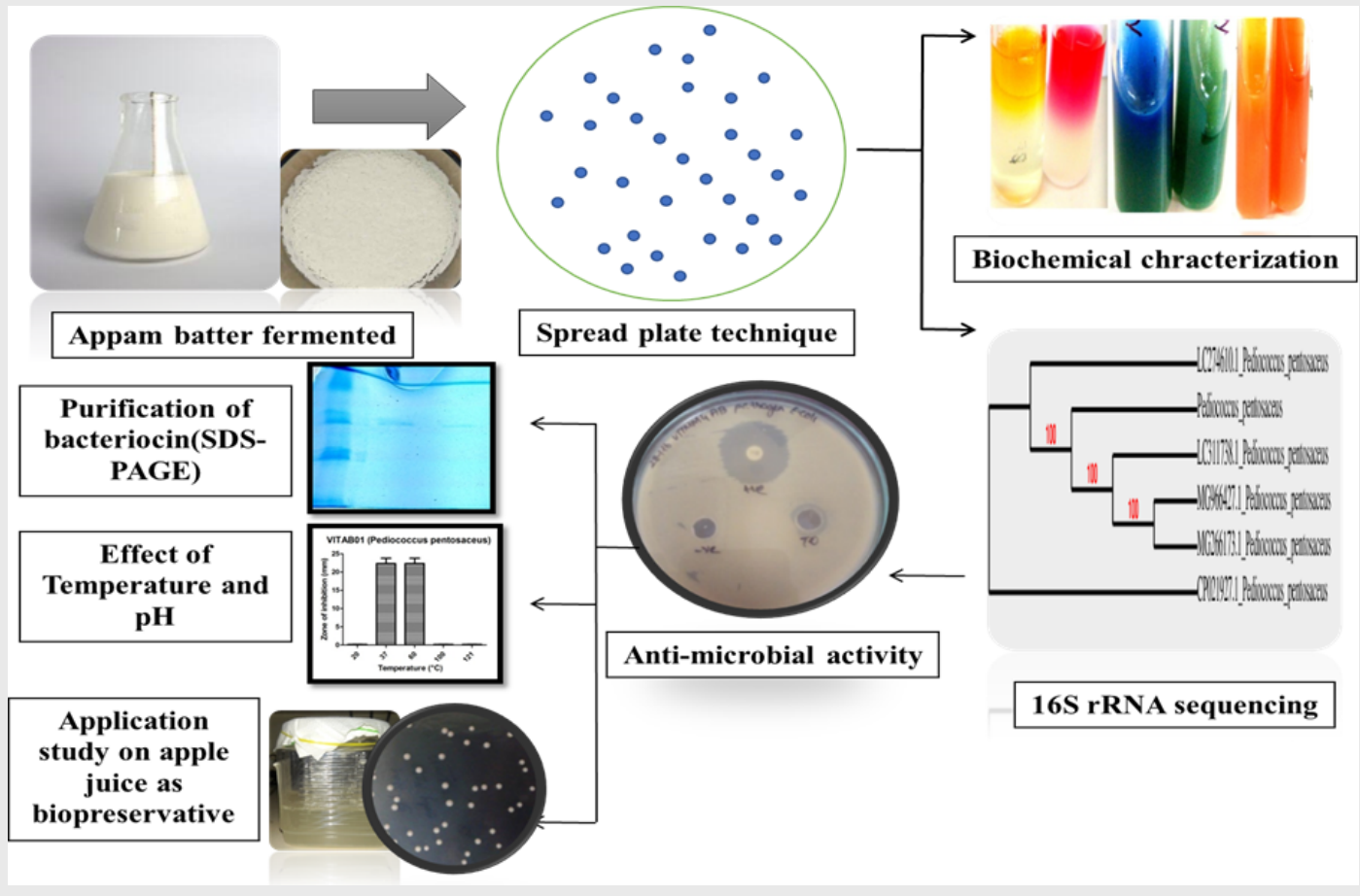

Cite this article: Majumder R, Aditya A, Dey S, Siddique JF, Anbalagan N, Devi S, Mohanasrinivasan V. Biopreservative Action of Bacteriocin from Pediococcus pentosaceus on the Microbial Load of Apple Juice. Indian $\mathrm{J}$ of Pharmaceutical Education and Research. 2021;55(1s):s242-s250. 